\title{
entrevista
}



DOI 10.20396/temáticas.v12i23/24.13597

\section{A INSTITUCIONALIZAÇÃO DOS ESTUDOS AMBIENTAIS}

Leila da Costa Ferreira ${ }^{1}$

Temáticas: Gostariamos que nos falasse sobre sua trajetória acadêmica.

Professora Leila C. Ferreira: Fiz um bacharelado em Ecologia na Unesp de Rio Claro no final dos anos 70 . Desde meu segundo ano de graduação iniciei minhas atividades de pesquisa na área de ambiente e sociedade com bolsas da Fapesp e CNPq. Além disso, tive forte experiência de militância política junto aos partidos clandestinos de esquerda tentando interligar a questão ambiental com a questão social.

Sou Mestre na área de sociologia ambiental e Doutora em Ciências Sociais, ambos pela UNICAMP, com dissertação e tese sobre Política Ambiental. Durante meu Doutorado fui contratada como Professora no Depto de Sociologia, em 1988, para introduzir a disciplina de Sociologia Ambiental na graduação do IFCH. Neste período, realizei ainda um estágio na Universidade de Moscou/Rússia sobre Populaçào, Meio Ambiente e Desenvolvimento durante 4 meses.

Desde a defesa de minha tese de doutoramento (em 1992), venho orientando alunos de graduação, mestrado e doutorado na área (em torno de 60 orientações já concluídas). Além disso, tenho publicado vários artigos sobre o tema de Políticas Públicas e a problemática ambiental, o

1 Professora titular $\mathrm{cm}$ Sociologia $\lambda$ mbicntal, Coordenadora do Doutorado $\mathrm{cm}$ Ambiente $\mathrm{C}$ Sociedade do Nepam/Unicamp c Presidente da Anppas. 
que me levou em 1995 a um pós-doutoramento nos EUA na Universidade do Texas, em Austin, sobre este tema, o que me propiciou a publicação de um livro pela Editora Boitempo, que no ano passado teve lançada sua segunda edição.

Nos últimos anos, passei a me interessar por aspectos mais teóri$\cos$ da interface entre ambiente e sociedade. Tenho orientado alguns alunos sobre o tema, tanto no Departamento de Sociologia (IFCH) quanto no Doutorado em Ambiente e Sociedade (IFCH/NEPAM), do qual sou coordenadora e responsável pelo curso "Teoria Social e Ambiente" (disciplina obrigatória do Programa).

Atualmente, além de assessora científica da FAPESP, CAPES, $\mathrm{CNPq}, \mathrm{SBPC}$ e Fundação Ford sobre questões ambientais, sou membro do Comitê Multidisciplinar da CAPES e Presidente da Associação Brasileira de Pesquisa e Pós-Graduação em Ambiente e Sociedade (ANPPAS).

Acabo de retornar da Inglaterra, da Universidade de York, onde estive trabalhando com Steve Yearley em projeto sobre "Teoria Social, Interdisciplinaridade e a Questão Ambiental na América Latina", que foi enviado para FAPESP como Projeto Temático. Por fim, encontra-se no prelo meu livro intitulado "Idéias para uma sociologia da questão ambiental no Brasil" (Ed. Anablume).

Temáticas: O que acha do termo 'meio ambiente'? Designa de modo satisfatório o que para você deveria designar?

Professora Leila: Não acredito no termo "meio ambiente". Na verdade, prefiro trabalhar com "questão ambiental", que diz respeito aos temas relevantes da teoria social contemporânea, ou relações ser bumano - natureqa, quando refletimos sobre as questões ecológicas, em uma perspectiva mais interdisciplinar. 
Temáticas: O quão relevante a discussão "Ambiente - Politica" lhe parece? De que maneira a antropologia/sociologia/ ciência politica pode(m) contribuir para os estudos sobre questões ambientais?

Professora Leila: Tal discussão é totalmente relevante. Podemos pensar em questões como biodiversidade, biotecnologia, mudanças globais etc. Até podemos refletir como estas questões podem auxiliar o Brasil na sua inserção no sistema internacional. Sem falar da relação entre pobreza e ambiente.

A sociologia ambiental tem contribuído fortemente para a discussão sobre Alta Modernidade, Sociedade de Risco e exclusão social; exemplos deste processo são os trabalhos de Beck, Giddens, Habermas e Castells, para citar somente alguns autores.

Temáticas: Quais são as dificuldades institucionais encontradas para o reconbecimento do tema como disciplina de pesquisa e ensino? Qual o gran de institucionalização dessa temática na academia brasileira?

Professora Leila: Hoje acredito que as dificuldades principais para a legitimidade da temática ambiental no interior das Ciências Sociais já estejam superadas; tanto internacionalmente quanto nacionalmente, este campo encontra-se consolidado. Do ponto de vista acadêmico, tal processo de institucionalização foi muito importante para ampliar o debate. Existem hoje no Brasil em torno de 30 programas (talvez 9 sejam os principais) nos quais pode-se trabalhar a interface sobre Ambiente e Sociedade. Além disso, no interior dos programas disciplinares, esta questão também tem sido tratada de forma sistemática, particularmente na UNICAMP. Cabe ressaltar ainda que se encontra no IFCH a única graduação em Ciências Sociais no Brasil que tem a disciplina de sociologia ambiental. No exterior, particularmente nos EUA e Europa, os estudos na área são bastante interessantes e vários centros já têm grupos importantes com renomados sociólogos. 
